\title{
Protective Effect of Supplementation with Powdered Mulberry Leaves on Glyphosate-Induced Toxicity in Catfish (Clarias gariepinus)
}

\author{
Sahar M. El-Sheshtawy ${ }^{1}$, Marwa M. Nada ${ }^{2}$, Maha S. Abd Elhafeez ${ }^{3 *}$, Dalia H. Samak ${ }^{4}$
}

${ }^{1}$ Toxicology Animal Health Research Institute (AHRI), Tanta Branch, Agriculture Research Centre (ARC), Dokki, Giza, Egypt; ${ }^{2}$ Pathology Department Animal Health Research Institute, (AHRI) Dokki, Agriculture Research Centre (ARC), Dokki, Giza, Egypt; ${ }^{3}$ Pharmacology Unit, Department of Chemistry, Toxicology and Feed Deficiency, Animal Health Research Institute (AHRI) Agriculture Research Centre (ARC), Dokki, Giza, Egypt; ${ }^{4}$ Department of Veterinary Forensic Medicine and Toxicology, Faulty of Veterinary Medicine, Damanhour University, 22516, Egypt.

\begin{abstract}
The prolonged-release of agricultural waste has led to an increase in the level of pesticides especially glyphosate which was reached in aquatic environments. Research has been carried out on catfish to detect the impacts of glyphosate and the protective effect of adding mulberry leaves powder against glyphosate on cat fish. Eighty immature catfish (Clarias gariepinus) were allocated into 4 groups; (G1) was maintained in the glyphosate-free water (G2) was exposed to $0.053 \mathrm{mg}$ glyphosate (Glyph) /1 water (1/10 96hr $\left.\mathrm{LC}_{50}\right),(\mathrm{G} 3)$ was exposed to M. albus leaves powdered (5\% ration supplementation) and (G4) was exposed to Glyph $(0.053 \mathrm{mg} / \mathrm{L})+$ M. albus (5\% from ration supplementation). At day 21 of the experiment, fish were taken for biochemical and histopathological examination and to determine its residues in muscle. Biochemical results indicated an elevation in serum alanine aminotransferase (ALT), aspartate aminotransferase (AST), Urea, creatinine, and malondialdehyde (MDA) in G2 group and reduction in G3 and G4 treated groups. While, Total protein (TP), albumin, $\mathrm{Ca}, \mathrm{Na}, \mathrm{Mg}$ ions, and reduced glutathione (GSH) significantly reduced in G2 group and elevate in G3 and G4 treated group. Several histopathological lesions were observed in the brain, gills, kidney, labyrinth organ, liver, and spleen in G2 and were improved after using $M$. albus in treated groups. The outcome of this study indicated that M.albus has to ameliorate the negative impacts of glyphosate on catfish through its antioxidant activity and the biologically active component which lead to improving in cat fish intoxicated with gyphosate.
\end{abstract}

Keywords | Glyphosate, M.albus, Catfish, Antioxidant, Residue, Histopathology.

Received | March 20, 2021; Accepted | June 29, 2021; Published | September 10, 2021

*Correspondence | Maha S. Abd Elhafeez, Department of Chemistry, Toxicology and Feed Deficiency, Animal Health Research Institute (AHRI) Agriculture Research Centre (ARC), Dokki, Giza, Egypt; Email: mahasabry86doc@gmail.com

Citation | El-Sheshtawy SM, Nada MM, Abd Elhafeez MS, Samak DH (2021). Protective effect of supplementation with powdered mulberry leaves on glyphosate-induced toxicity in catfish (Clarias gariepinus). Adv. Anim. Vet. Sci. 9(10): 1718-1731.

DOI | http://dx.doi.org/10.17582/journal.aavs/2021/9.10.1718.1731

ISSN (Online) | 2307-8316; ISSN (Print) | 2309-3331

Copyright (C) 2021 El-Sheshtawy et al. This is an open access article distributed under the Creative Commons Attribution License, which permits unrestricted use, distribution, and reproduction in any medium, provided the original work is properly cited.

\section{INTRODUCTION}

$\mathrm{U}$ sing of large amount from different types of pesticides in many applications by different methods as direct application, spray drift, runoff, drainages from industries and wastewater which have potentially bad impacts on the aquatic ecosystem (Katagi, 2010). In particular, using of the herbicides in different agricultural types and reach aquatic organisms such as fish which is highly affected (Adedeji and Okocha, 2012). Fish is the most appropriate and attractive model for experimental researches on humans and other environmental health especially in toxicological and some pharmacological studies (Govind, 2011).

In general, the glyphosate-based herbicide is used in different agriculture practices, fishponds, lakes, canals, and slow running water to get rid of harmful plants. The toxic effect of glyphosate on aquatic and non-aquatic organism 
depend on the disturbance in the metabolic and biological enzyme which lead to an imbalance in their ecological system (Annett et al., 2014). In response to glyphosate toxicity, there are many studies related to glyphosate basedherbicide toxicity in fish as the metabolic disorders which occurred due to exposure to it (Glusczak et al., 2011). The main end product of glyphosate biotransformation is aminomethyl-phosphonic acid (AMPA). Its residue was detected in natural water resource, in ditches, drains, soils, rivers, sediment, rainwater, stream and also in various types of foods in many countries which commonly use glyphosate (Battaglin et al., 2014). There are several kinds of research related to herbicide induced toxicity as hepatic destruction, antibiotic resistance, and renal damage (Bai and Ogbourne, 2016). Also, several neurological diseases like autism, Parkinson's disease, and anxiety disorder have been recorded in the case of glyphosate toxicity (Gallegos et al., 2016). The disturbance in cellular and biochemical parameters are the most sensitive indicator in fish that was exposed to aquatic environmental pollutants (Sandrini et al., 2013). The imbalance in the oxidative stress /antioxidant system was the first line in glyphosate intoxication in different biological systems (Sánchez et al., 2017). As a result of this oxidative destruction the macromolecules as DNA, lipids, and proteins were affected due to ROS formation and the lowering the cellular antioxidant levels in organisms and fish (Boligon et al., 2015). Recently, herbal remedies are the natural resources of biologically active compounds (Ji et al., 2009), which have received the attention of the medicinal system and the industry of pharmacy all over the world. This natural medicinal extract is used in the treatment and prevent the most of common diseases which may be threat human and life in the long or short-run (Cao et al., 2018). From these famous medicinal plants, mulberry has characteristic active ingredients like stilbenoids, phenols, terpenoids, alkaloids, and amino sugars (Thakur et al., 2019). Also, the mulberry leaves (Morus alba), root, and fruit have a lot of biologically active compound as antimicrobial, antioxidant, skin-whitening, anti-inflammatory cytotoxic, anti-diabetic, anti-platelet, anxiolytic, anti-asthmatic, anthelmintic, antidepressant glucosidase inhibition, anti-hyperlipidemic, anti-atherosclerotic, anti-obesity, cardioprotective, hepatoprotective, and immunomodulatory activities (Chan et al., 2016). The aim of this study was to investigate the subacute toxicity of glyphosate on catfish and assessment the possible protective effects of Morus alba depending on the analysis the biochemical parameter, serum oxidative stress (MDA and GSH), glyphosate residue in muscle and histopathological examination of fish organs.

\section{MATERIALS AND METHODS}

\section{FISH AND GLASS AQUARIA}

A round of (80) seemingly healthy immature catfish
(Clarias gariepinus) including both sexes with bodyweight $(150 \pm 20 \mathrm{~g})$ has been collected from private farm fish in Tanta province. Before the beginning of the experiment, catfish were acclimatized for two weeks in eight glass fish tanks $(100 \times 50 \times 50 \mathrm{~cm} / \mathrm{each})$ filled with tap water free chlorines under experimental conditions (natural photoperiod $11.58 / 12.38 \mathrm{~h}$ and temperature $25.8 \pm 1.8^{\circ} \mathrm{C}$ ). The aeration process was constant and fixed in all fish tanks using the air pump. Commercially, the ration was used for catfish usually at $3 \%$ of body weight daily contain $25 \%$ protein. Dissolved oxygen, temperature, ammonia, and $\mathrm{pH}$ of experimental water was used according to WHO (2001).

\section{TEST CHEMiCAL}

Commercially grade glyphosate-based herbicides (GLYPHO ELNASR 48\%SL ${ }^{\circledR}$ ) (Intervet Co., China) were used in this study (N-(phosphonomethyl- glycine, isopropylamine salt) was adding to water in each catfish aquarium and the purchased Morus albus leaves (MORUS ALBA LEAVES, Box, Bag, Colour: Green, Brand; Leaves veg India: India, item code; 54559512) were chemically analyzed according to AOAC (2000).

\section{EXPERIMENTAL PROCEDURES}

Twenty-one day for subacute toxicity was done by using $\left(1 / 1096 \mathrm{hr} \mathrm{LC}_{50}\right)$ of glyphosate was added to tested catfish (20 fish for each). The study was done in aquarium each contains 100 liters of water and 10 fish. Two aquariums were used for each group and the requested concentration was kept and replenished daily by siphoning and substituted by the same amount of water. A control group (G1) (20 catfish) was put in glyphosate free fish tanks along the time of the experimental, glyphosate (Glyph), G2 was exposed to $\left(1 / 1096 \mathrm{hr} \mathrm{LC}{ }_{50}\right)$ glyphosate in concentration $0.053 \mathrm{mg} / \mathrm{L}$ (Ayanda et al., 2015). G3 (M. albus) was exposed to $M$. albus leaves powdered (5\% ration supplementation) (Hou et al., 2020) and finally G4 was exposed to Glyph (0.053 $\mathrm{mg} / \mathrm{L})+$ M. albus (5\% from ration supplementation). At day 21 of the experiment, the fish were taken for biochemical, histopathological examination and residue determination in muscle. The tested fish were regularly followed-up daily along the experimental period. The experimental protocols and procedures were approved by Animal Health Research Institute (AHRI), Tanta Branch, Agriculture Research Centre (ARC), Giza, Egypt with approved number: (AHRI; 31122019).

\section{SAMPLING PREPARATION}

Throughout the study end, blood samples were collected from the caudal vein of catfish in a test tube and set for $30 \mathrm{~min}$ for coagulation followed by centrifugation (3000 rpm for $15 \mathrm{~min}$ ) and preserved at $-20{ }^{\circ} \mathrm{C}$ until using for measuring the liver and kidney enzymes and electrolytes level. Immediately, the liver was removed and cleaned with 
sterile saline was used for detection of oxidant/ antioxidant parameters, samples from gills, liver, kidneys, labyrinth organ, spleen, and brain were used for pathological examination.

The fish muscles were analyzed for determination of glyphosate residue as described by Sun et al. (2017).

\section{THE BIOCHEMICAL SERUM PROFILES}

Serum alanine aminotransferase (ALT), aspartate aminotransferase (AST) activity, albumin, and total protein were detected as described by Reitman and Frankel (1957), Doumas et al. (1997), and Henry et al. (1947), respectively. Furthermore, serum creatinine and urea were detected by spectrophotometer as recorded by Perakis and Wolff (1984) and Searcy (1967), respectively.

\section{BIOCHEMICAL SERUM ELECTROLYTES DETERMINATION}

Using the commercial electrolytes available kits as Sodium $\left(\mathrm{Na}^{+}\right)$, Magnesium concentrations $\left(\mathrm{Mg}^{+}\right)$, and Calcium concentrations $\left(\mathrm{Ca}^{+}\right)$were estimated calorimetrically according to the methods described by Trinder (1969), Thomas (1998), and AHB (2006), respectively.

\section{OXIDANT/ANTIOXIDANT DETECTION IN HEPATIC}

\section{HOMOGENATES}

Malondialdehyde (MDA) is the indicator of oxidative stress and the reduced glutathione (GSH) which is considered a biomarker of antioxidant parameters were determined spectrophotometrically as recorded by Ohkawa et al. (1979) and Beutler (1963).

\section{DETERMINATION OF GLYPHOSATE RESIDUE IN FISH} MUSCLE

Chemical REAGENTS

Glyphosate (99\%) and 9-fluorenyl-methyl-chloroformate (FMOC-Cl, 97.0\%) were taken from Sigma Aldrich (St. Louis, Mo, USA). Acetonitrile HPLC grade was purchased from Merck (Darmstadt, Germany) while other chemicals used in extraction were analytical grade solvents. Deionized water was used for all experiments and obtained from a Millipore Milli-Q System (Millipore Co., MA, USA).

\section{Preparation OF THE STANDARD SOlUTIONS}

The stock solution of Glyphosate standard was prepared in deionized water at a concentration of $1000 \mathrm{ppm}$, and this standard solution was stored in dark bottles at $4^{\circ} \mathrm{C}$. Sodium tetraborate in deionized water $(50 \mathrm{mM} / \mathrm{L})$ and FMOC dissolved in acetonitrile $(1 \mathrm{~g} / \mathrm{L})$ were used for the derivatization process. The standards for plotting of the calibration curve were prepared in the blank fish muscle at range $(0.1-2 \mu \mathrm{g} / \mathrm{kg})$ then extracted as described below in sample preparation.

\section{SAMPLE PREPARATION}

Glyphosate were extracted and purified from fish muscle as described by Sun et al. (2017).

\section{Chromatographic CONDiTIONS}

The parameters of the HPLC method were illustrated in a Table 1.

Table 1: Chromatography conditions of HPLC method.

\begin{tabular}{lll} 
Mobile phase & \multicolumn{1}{c}{$\begin{array}{c}\text { Gradient (acetonitrile (A) and 0.2\% v/v } \\
\text { phosphoric acid aqueous solution (B) } \\
\text { Mobile phase B }\end{array}$} \\
& Time & $35 \%$ \\
& 0 & $25 \%$ \\
& 10 & $80 \%$ \\
& 15 & $35 \%$ \\
& 20 & \\
\hline Column type & $\mathrm{C} 18,5 \mu \mathrm{m}, 250 \mathrm{~mm}, 4.6 \mathrm{~mm}$ \\
Column temperature & $35^{\circ} \mathrm{C}$ \\
\hline Flow rate & $1 \mathrm{ml} / \mathrm{min}$. \\
\hline FLD wavelength & $254 \mathrm{~nm}$ of excitation and $301 \mathrm{~nm}$ of emission \\
\hline Stop time & $20 \mathrm{~min}$. \\
\hline Injection volume & $20 \mu \mathrm{l}$
\end{tabular}

\section{Pathological examination}

Fish of all experimental groups were subjected to postmortem examination and then fresh tissue specimens from gills, liver, spleen. kidneys, labyrinth organ and brain were quickly put in neutral formalin solution $10 \%$ for at least one day for pathological examination according to Suvarna et al. (2013).

\section{STATisTiCAl ANALYSis}

Data of this study were analyzed for detection differences among the groups through using one way a nova computer program (ANOVA) of the Statistical Analysis System was found by Tukey's HSD post hoc test using statistical (Sas, 2001). The study results are represented as the mean \pm standard error with differences $P \leq 0.05$ is statistically significant.

\section{RESULTS AND DISCUSSION}

\section{LIVER AND KIDNEY FUNCTION}

The adverse effect of a glyphosate-based herbicide on catfish and the potential protective role of $M$. albus leave powder on serum liver and kidney function biomarkers are recorded. In comparison with control, serum ALT and AST enzyme activities were significantly elevated in the glyphosate intoxicated group and significantly reduced in M. alba and in the treated group (M. alba/Glyh). While, there was a statically decrease in total protein and albumin in the intoxicated glyphosate group, and there is no statistically significant detection were recorded in $\mathrm{M}$. alba and treated group in relation to control. But there is 
a significant elevation in the glyphosate intoxicated group after using M.alba in the treated group. Creatinine and urea were significantly elevated in the intoxicated group with glyphosate and a significant reduced in the treated group with $\mathrm{M}$. alba and in the combination $(\mathrm{Glyh}+M$. albus) treated group were observed in Table 2.

\section{SERUM ElECTROLYTES DETERMINATION}

Calcium,sodium, and magnesiumelectrolyteconcentrations were statistically reduced in glyphosate intoxicated group concerning with control and a significant increase in $\mathrm{M}$. alba and in the combination-treated group (GLyh $+M$. albus) in all mineral except $\mathrm{Ca}$ concentration were reduced in relation to control and increased in relation to the intoxicated group as in Table 2.

\section{MDA AND GSH DETECTION}

In comparison with control, there is a significant elevation in MDA in the intoxicated group with glyphosate, and a significant reduction in $\mathrm{M}$. alba and the combinationtreated group (M. alba/ Glyph) was observed. In contrast, GSH the indicator of the antioxidant system was observed significantly reduced in the intoxicated group with glyphosate. While there is a significant increase was observed in M. alba/ Glyph treated group in relation to the intoxicated group as in Table 3.

\section{GlyPhosate RESIDUe IN FISH MUSCLE BY HPLC}

According to USP (2019) the method was validated and the validation results were summarized in Table 4 . The standard curve of glyphosate concentration versus peak area was detected in Supplementary Figure S1. The obtained results showing that the used method was accurate, precise and robust as detected in Figures 1 and 2).

The levels of glyphosate in fish muscle were mentioned showing no significance in glyphosate intoxicated groups and glyphosate with mulberry in the treated group as shown in Figure 3.

\section{THE MACROSCOPICAL EXAMINATION}

Macroscopical examination of the control and Mulberry groups showed normal macroscopical picture of the internal organs. While the Glyphosphate group exhibited hyperemic gills with mucous secretions. The kidneys and livers were pale in color with congested vasculatures. The labyrinth organ exhibited hard in texture and the spleens were pale in color. On the other hand, the Mulberry treated group showed no marked gross lesions.

\section{THE HISTOPATHOLOGICAL EXAMINATION}

The histopathological examination of catfish brain in comparison with the control group (C) which was appeared with normal basophilic neurons, normal brain parenchyma, and normal white matter nerve fibers in the brain as in Supplementary Figure S2C. The intoxicated group with glyphosate Supplementary Figure S2 G(a) the brain revealed many pathological lesions as severe acidophilic necrosis of neurons with cavitation (motheaten appearance) around the neurons with thrombosis of blood capillaries. The brain in Supplementary Figure S2.G(b) showed severe degeneration and spongiosis of white matter nerve fibers. While the $M$. albus group appeared with high intact neurons with basophilic neurons bodies Supplementary Figure S2 M(a) and normal neuron fibers in white matter Supplementary Figure S2 M(b) in contrast with intoxicated and control group. The protected group Supplementary Figure S2(T) brain appeared with normal basophilic structure of most of neurons with few individual necrosis of other neurons and perineuronal edema and effect were high in white matter nerve fibers which appeared intact except for mild degeneration of neuron fibers Supplementary Figure S2(T). The chart showed that the brain of intoxicated fish with glyphosate have Gray matter neurons necrosis and cavitation and White matter nerve fibers degeneration and thrombus formation, while this lesion was disappeared from CTR and another treated group and improved in treated group with $(\mathrm{Glyh}+M$. albus) Figure 4.

Table 2: Effect of Mulberry Albus leaves on cat fish intoxicated with glyphosate on serum liver and kidney parameters for 21 days. Glyph, Glyphosate; mullbery albus leaves, M.Albus; M.Albus/Glyph (treated group).

$\begin{array}{lllll} & \text { CTR } & \text { Glyph } & \text { M. Alba } & \text { M. Alba } / \text { Glyph } \\ \text { ALT u/l } & 32.20 \pm 1.50^{\mathrm{b}} & 77.00 \pm 3.27^{\mathrm{a}} & 28.20 \pm 1.28^{\mathrm{c}} & 38.76 \pm 1.07^{\mathrm{b}} \\ \mathrm{AST} \mathrm{u} / \mathrm{l} & 38.00 \pm 1.14^{\mathrm{b}} & 102.00 \pm 2.63^{\mathrm{a}} & 37.50 \pm 0.81^{\mathrm{b}} & 42.40 \pm 0.93^{\mathrm{b}} \\ \text { Total protein gm/dl } & 07.86 \pm 0.06^{\mathrm{a}} & 05.86 \pm 0.13^{\mathrm{b}} & 07.96 \pm 0.08^{\mathrm{a}} & 07.86 \pm 0.07^{\mathrm{a}} \\ \text { Albumin } \mathrm{g} / \mathrm{dl} & 04.16 \pm 0.05^{\mathrm{a}} & 02.92 \pm 0.09^{\mathrm{c}} & 04.18 \pm 0.04^{\mathrm{a}} & 03.90 \pm 0.04^{\mathrm{b}} \\ \text { Creatinine } \mathrm{mg} / \mathrm{dl} & 00.87 \pm 0.05^{\mathrm{c}} & 02.52 \pm 0.09^{\mathrm{a}} & 00.82 \pm 0.04^{\mathrm{c}} & 01.18 \pm 0.04^{\mathrm{b}} \\ \mathrm{Urea} \mathrm{mg} / \mathrm{dl} & 23.26 \pm 0.51^{\mathrm{c}} & 46.60 \pm 0.93^{\mathrm{a}} & 27.25 \pm 0.49^{\mathrm{b}} & 29.00 \pm 0.71^{\mathrm{b}} \\ \mathrm{Ca} \mathrm{mmol} / 1 & 09.32 \pm 0.04^{\mathrm{a}} & 07.40 \pm 0.16 \mathrm{c} & 09.28 \pm 0.04^{\mathrm{a}} & 08.74 \pm 0.10^{\mathrm{b}} \\ \mathrm{Na} \mathrm{mmol} / 1 & 136.60 \pm 1.03^{\mathrm{a}} & 126.60 \pm 0.75^{\mathrm{b}} & 136.60 \pm 0.51^{\mathrm{a}} & 137.40 \pm 0.51^{\mathrm{a}} \\ \text { Mg mmol/1 } & 03.74 \pm 0.07^{\mathrm{a}} & 02.66 \pm 0.09^{\mathrm{b}} & 03.72 \pm 0.06^{\mathrm{a}} & 03.76 \pm 0.05^{\mathrm{a}} \\ \text { All values were expressed as mean } \pm \text { standard errors }(n=20) \text {. All values indicated by different letters are significantly different between } \\ \text { groups within the same rows }(p \leq 0.005) .\end{array}$


Table 3: Effect of Mulberry Albus leaves on cat fish intoxicated with glyphosate on oxidant/ antioxidant parameters for 21 days. Glyph, Glyphosate; mullbery albus leaves, M.Albus; M.Albus/ Glyph (treated group).

\begin{tabular}{|lll|} 
& MDA nmol/g. tissue & GSH mg. tissue \\
CTR & $03.52 \pm 0.10^{\mathrm{b}}$ & $03.96 \pm 0.21^{\mathrm{a}}$ \\
Glyph & $11.43 \pm 0.32^{\mathrm{a}}$ & $00.97 \pm 0.05^{\mathrm{c}}$ \\
\hline M. Alba & $01.68 \pm 0.12^{\mathrm{c}}$ & $04.12 \pm 0.16^{\mathrm{a}}$ \\
\hline M. Alba /Glyph & $03.58 \pm 0.11^{\mathrm{b}}$ & $02.94 \pm 0.09^{\mathrm{b}}$ \\
\hline
\end{tabular}

All values were expressed as mean \pm standard errors $(n=20)$. All values indicated by different letters are significantly different between groups within the same columns $(p \leq 0.005)$.

Table 4: Validation sheet for method validation.

\begin{tabular}{|c|c|c|}
\hline Parameter & Results & $\begin{array}{l}\text { Acceptance } \\
\text { criteria }\end{array}$ \\
\hline Range & $0.1-2 \mu \mathrm{g} / \mathrm{kg}$ & \\
\hline Slope & 721.7 & \\
\hline Intercept & -26.292 & \\
\hline Correlation coefficient & 0.9992 & $>0.99$ \\
\hline Accuracy & $103.7 \pm 9.8$ & $80-120 \%$ \\
\hline Intraday precision (RSD\%) & $0.07 \%$ & $<1 \%$ \\
\hline Interday precision (RSD\%) & $1.28 \%$ & $<2 \%$ \\
\hline Robustness (pooled RSD\%) & $1.5 \%$ & $<6 \%$ \\
\hline System suita- Tailing factor & $0.098 \pm 0.003$ & $<2 \%$ \\
\hline bility testing Peak area (RSD\%) & $0.34 \%$ & $<1 \%$ \\
\hline (SST) Theoretical plate & $9212.3 \pm 71.5$ & $>2000$ \\
\hline $\begin{array}{l}\text { Retention time } \\
\text { (RSD\%) }\end{array}$ & $\begin{array}{l}7.9 \pm 0.05 \\
(0.6 \%)\end{array}$ & $<2 \%$ \\
\hline
\end{tabular}

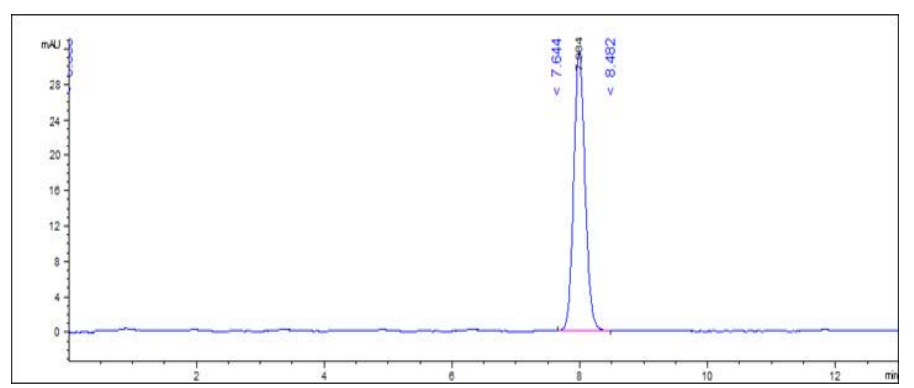

Figure 1: Chromatogram of glyphosate standard at a conc. of $0.2 \mathrm{ppm}$.

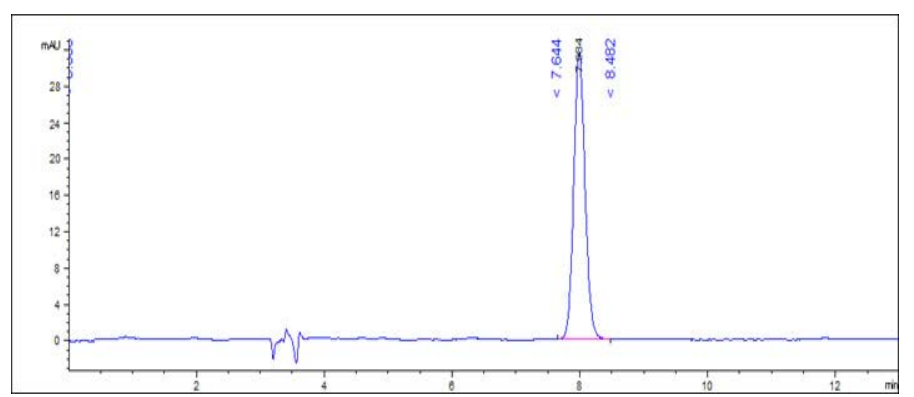

Figure 2: Chromatogram of glyphosate in blank fish muscle at a conc. of $0.2 \mathrm{ppm}$.

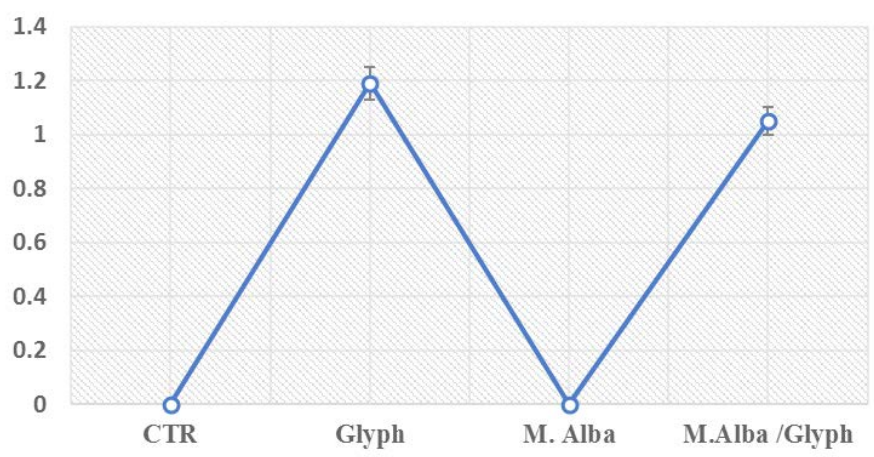

Figure 3: Glyphosate concentrations in fish muscle ( $\mu \mathrm{g} /$ $\mathrm{kg}$ ) showed no significant changes among intoxicated group with glyph and treated intoxicated group (glyph/ $M$. albus) at twenty-one day in cat fish

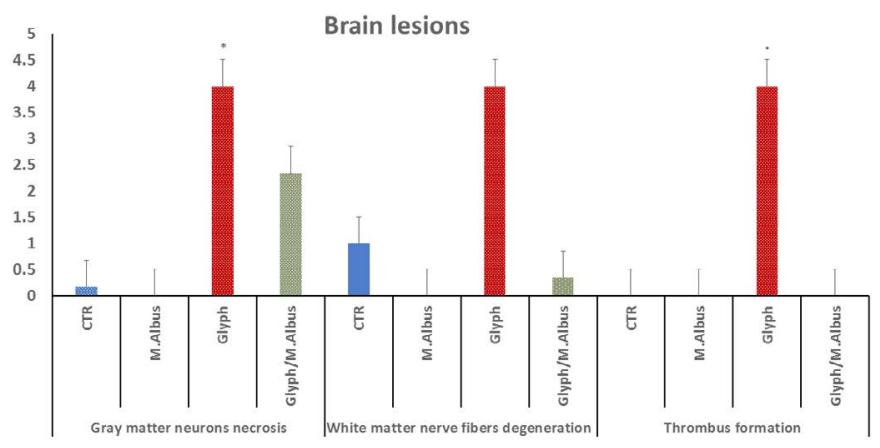

Figure 4: Showing that the brain of intoxicated fish with glyphosate have enhanced gray matter neurons necrosis, white matter nerve fiber degeneration and thrombus formation, while these lesions were dissppeared from CTR and other treated group and improved in treated group with (Glyh+M.albus). Data expressed as Mean \pm $\mathrm{SE}$, analyzed using one-way ANOVA at $\mathrm{P} \leq 0.05$, column with $\left({ }^{*}\right)$ indicate significant difference among the values of different groups. ( $\mathrm{C}=\mathrm{Control}, \mathrm{G}=\mathrm{glyph}, \mathrm{M}=M$. albus, $\mathrm{T}=(\mathrm{Glyph} / M$. albus $)$.

Fish gills showed normal primary and secondary gill filament with normal cells structure and central blood supply of gill filaments Supplementary Figure S3(C). The glyphosate intoxicated group showed necrosis and degeneration of all cellular structures of gill filament and loss of secondary filaments cellular Supplementary Figure S3 G(a). Some parts of gills showed inter lamellar hyperplasia, inflammatory infiltration of mononuclear cells of gill filaments with mucus cells proliferation, and chondrocytes proliferation in the center of gill filaments with the lamellar fusion of gill secondary filaments in the upper part. Supplementary Figure S3 G(b). In comparison with the control Supplementary Figure S3(C). The mulberry group revealed highly intact healthy gill filaments with central blood supply as in Supplementary Figure $\mathrm{S} 3(\mathrm{M})$ in comparison with the intoxicated and control group. 


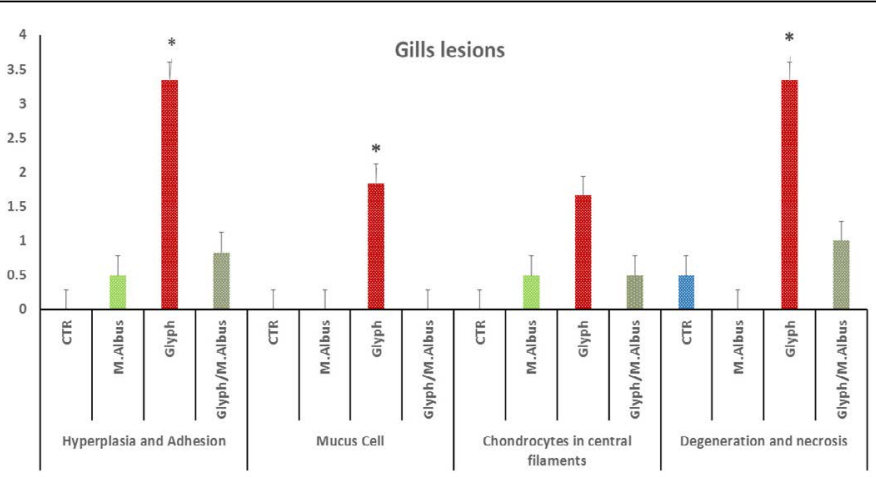

Figure 5: Showing that the gills of fish intoxicated with glyphosate have enhanced hyperplesia and adhesion of gill filaments, mucus cell, chondrocytes proliferation in centeral filaments and degeneration and necrosis of gill filaments, while these lesions were dissppeared from CTR and other treated group and improved in treated group with $(\mathrm{Glyh}+M$. albus $)$. Data expressed as Mean \pm $\mathrm{SE}$, analyzed using one-way ANOVA at $\mathrm{P} \leq 0.05$, column with $\left(^{*}\right)$ indicate significant difference among the values of different groups. ( $\mathrm{C}=\mathrm{Control}, \mathrm{G}=\mathrm{glyph}, \mathrm{M}=M$. albus, $\mathrm{T}=(\mathrm{Glyph} /$ M. albus $)$.

The protected group showed improvement in gill filaments structure with the still presence of mild gill necrosis and some chondrocytes in the central part of filaments Supplementary Figure S3 (T). in addition to the chart of the gills of fish intoxicated with glyphosate recorded hyperplasia and adhesion, mucus cell, chondrocytes in central filaments and degeneration and necrosis, while that lesion was disappeared from CTR and another treated group and improved in treated group with $(\mathrm{Glyh}+M$. albus) Figure 5.

The labyrinth organ of control which revealed a normal central elastic cartilage and peripheral maize like structure epithelial cells with normal blood capillaries and the suparbranchial organ tree-like structure from the second and fourth-gill arches allows the catfish to take oxygen directly from the air for short period Supplementary Figure S4 (C). the labyrinth organ has a pathological lesion in the intoxicated group with glyphosate as the following conversion of elastic cartilage into fibrocartilage with necrosis and degeneration of epithelial lining the outer structure Supplementary Figure S3 G(a) and thrombosis of blood capillaries as in Supplementary Figure S3 G(a, c). The mulberry group exhibited normal structure as in Supplementary Figure S3 (M). While the treated group showed high protection from fibrocartilage degeneration and exhibited normal elastic cartilage with few mild degeneration Supplementary Figure S3(T). Aslo, the labyrinth organ chart of intoxicated fish with glyphosate have detect a fibrocartilage formation, degeneration of Maize like epithelial cell and thrombus formation, while this lesion was disappeared from CTR and other treated group and was improved in treated group with $(\mathrm{Glyh}+M$. albus) Figure 6.

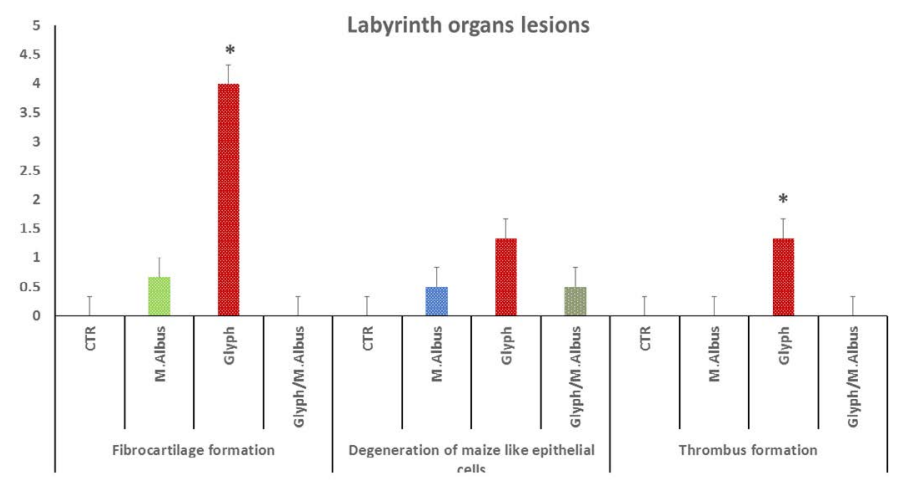

Figure 6: Showing that labryinth organ of fish intoxicated with glyphosate have enhanced fibrocartilage formation, degeneration of Maize like epithelial cell and thrombus formation, while these lesions were dissppeared from CTR and other treated group and improved in treated group with $(\mathrm{Glyh}+M$. albus $)$. Data expressed as Mean \pm $\mathrm{SE}$, analyzed using one-way ANOVA at $\mathrm{P} \leq 0.05$, column with $\left(^{*}\right)$ indicate significant difference among the values of different groups. ( $\mathrm{C}=\mathrm{Control}, \mathrm{G}=\mathrm{glyph}, \mathrm{M}=\mathrm{M}$.albus, $\mathrm{T}=($ Glyph/M.albus).

The kidneys in control group showed healthy glomerular corpuscles, intact renal tubular epithelium, and normal circumscribed blood vessels Supplementary Figure S5 (C). While the intoxicated group showed degeneration of renal tubular epithelium and some sloughed into the lumen, atrophy of glomerular corpuscles, and interstitial fibrosis Supplementary Figure S5 G(a) blood vessels in kidneys revealed folding of all wall tunics into the lumen with thickening in the wall Supplementary Figure S5 $G(b)$, thrombosis in the lumen of blood vessels attached to the wall with accumulated RBCs and leukocytes were recorded Supplementary Figure S5 G(c). In contrast in $M$. albus group revealed high normal intact renal glomeruli, healthy tubular epithelium, and normal renal blood vessels Supplementary Figure S5 (M) in comparison with intoxicated and control one. Also, the protected group appeared high intact renal glomeruli, but still present the degree of degenerative changes of some renal tubular epithelium Supplementary Figure S5 T(a) renal blood vessels with normal circumscribed vessels wall with normal thickness Supplementary Figure S5 T(b). In addition, the kidney of fish intoxicated with glyphosate has degeneration, necrosis sloughing of epithelial renal, glomerular atrophy, blood dilation and folding, blood capillary thickness, thrombus in blood capillary, complete necrosis of tissue and interstitial fibrosis, while this lesion were disappear from CTR and other treated group and improved in treated group with $(\mathrm{Glyh}+M$. albus $)$.as presented in Figure 7.

The hepatic tissue of the control showed a normal 
thickness Supplementary Figure S6(C), while in the intoxicated group with glyphosate showed thickening of the portal vein and hyalinization with folding into the lumen Supplementary Figure S6(G). The mulberry group revealed normal thickness of the vessel's wall Supplementary Figure S6(M), and the protected group revealed high normal with the thin-walled thickness of portal vein as in Supplementary Figure S6(T). Liver of fish intoxicated with glyphosate have hepatocytes necrosis, central vein dilated and thickening of the wall and folding in lumen and no changes in bile duct were recorded, while this lesion was disappeared from CTR and other treated group and improved in treated group with $(\mathrm{Glyh}+M$. albus) Figure 8.

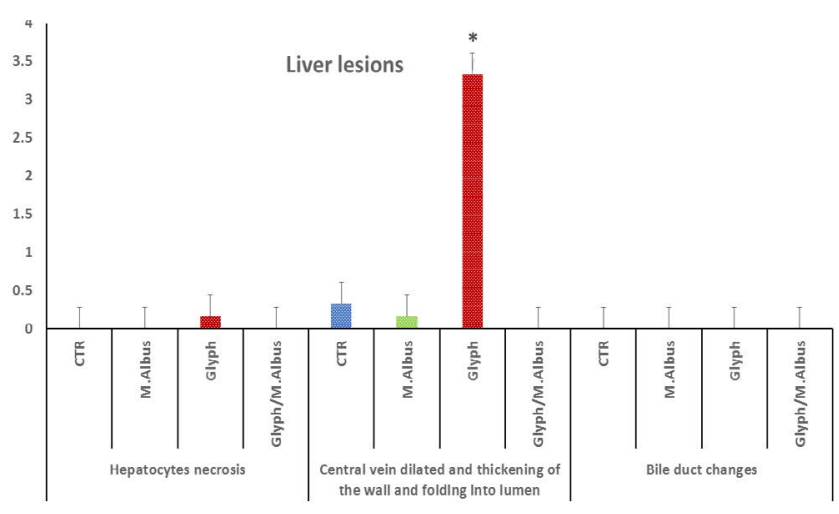

Figure 7: Showed that the kidney of fish intoxicated with glyphosate have degeneratin ,necrosis sloughing of epithelial renal tubuli, glomerular atrophy, blood dialation and flolding, blood caplliary thickness, thrombus in blood capillary, complete necrosis of tissue and intersititial fibrosi, while theses lesions were dissppeared from CTR and other treated group and improved in treated group with (Glyh+M.albus). Data expressed as Mean $\pm \mathrm{SE}$, analyzed using one-way ANOVA at $\mathrm{P} \leq 0.05$, column with $\left(^{*}\right)$ indicate significant difference among the values of different groups. ( $\mathrm{C}=\mathrm{Control}, \mathrm{G}=\mathrm{glyph}, \mathrm{M}=M$. albus, $\mathrm{T}=(\mathrm{Glyph} /$ M. albus $)$

The spleen of the control group showed white pulp impacted with lymphocytes and the central arteriole with normal diameter Supplementary Figure S7 C(a). In mulberry treated group showed an increase in population of lymphocytes in white pulp as in Supplementary Figure S7 $\mathrm{M}(\mathrm{a})$ and increase periarterial lymphatic sheath Supplementary Figure S7 M(b) while, the protected group exhibited increase in lymphocytes in a white pulp with dilated blood vessels wall Supplementary Figure S7 (T). that the spleen intoxicated with glyphosate have enhanced depletion of lymphocytes in white pulb, but the increase lymphocytes in white pulp with dilated blood vessels and increase in periarterial lymphatic sheath were recorded in mullberry group, and treated group $(\mathrm{Glyh}+M$. albus $)$ Figure 9.

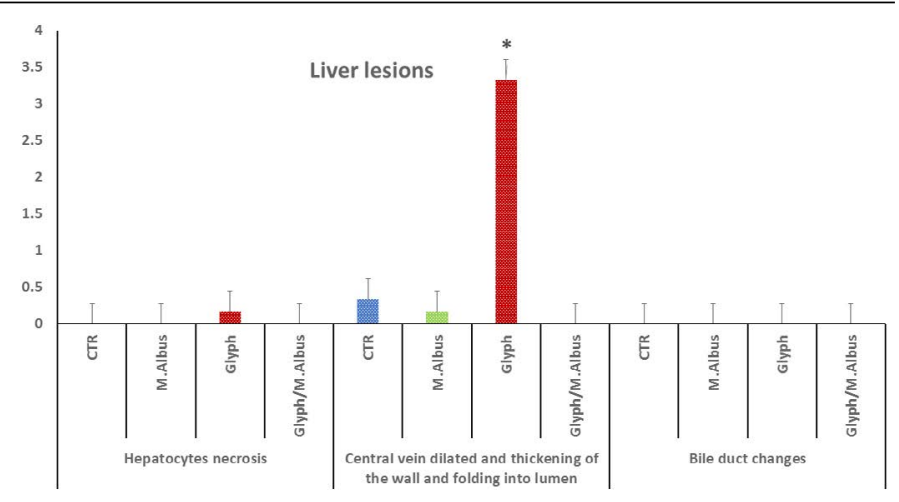

Figure 8: Showing that liver of fish intoxicated with glyphosate have hepatocytes necrosis, central vein dialtation and thickening of the wall and folding in lumen and no changes in bile duct were recorded, while these lesions were dissppeared from CTR and other treated group and improved in treated group with $(\mathrm{Glyh}+M$. albus). Data expressed as Mean $\pm \mathrm{SE}$, analyzed using one-way ANOVA at $\mathrm{P} \leq 0.05$, column with $\left(^{*}\right)$ indicate significant difference among the values of different groups. ( $\mathrm{C}=$ Control, $\mathrm{G}=$ glyph, $\mathrm{M}=M$. albus, $\mathrm{T}=(\mathrm{Glyph} / M$. albus $)$.

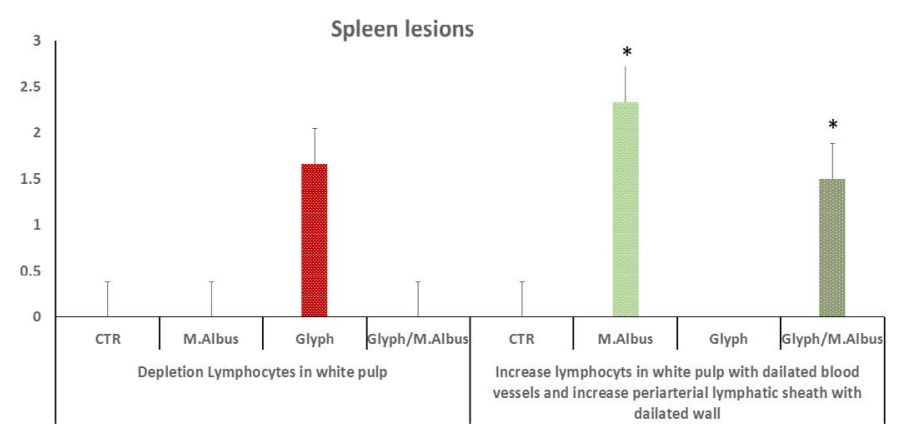

Figure 9: $\mathrm{C}$ showing that the spleen of fish intoxicated with glyphosate have enhanced depletion of lymphocytes in white pulb, but the increase lymphocytes in white pulp with dilated blood vessels and increase in periarterial lymphatic sheath were recorded in mullberry group,and treated group. Data expressed as Mean $\pm \mathrm{SE}$, analyzed using one-way ANOVA at $\mathrm{P} \leq 0.05$, column with $\left(^{*}\right)$ indicate significant difference among the values of different groups. $(\mathrm{C}=$ Control, $\mathrm{G}=$ glyph, $\mathrm{M}=M$. albus, $\mathrm{T}=(\mathrm{Glyph} / M$. albus $)$.

The eco-environment is widely affected by different types of pesticides from different sources. The disturbance in the aquatic environment may be due to several factors one of them is the elevation of herbicides concentrations due to the huge using in different agricultural practices with a large amount, and the fish is considered an avital monitor in ecotoxicology research (Glusczak et al., 2011). The presence of high-level glyphosate in the aquatic environment has received much interest in the research study due to its detrimental consequences on the living organism. Numerous studies have reported oxidative stress effect which was occurred during glyphosate intoxication is mainly an effect on biological systems (Sánchez et al., 
2017). Accordingly, glyphosate is likely to provoke the deregulation of many biological metabolic pathways that may lead to the destruction of DNA, lipids, and proteins from ROS generation that elevate the level of oxidative damage and lowering cellular antioxidant levels in aquatic organisms (Boligon et al., 2015; Chaufan et al., 2014). Current biochemical studies have already demonstrated that glyph has increased the level of oxidative stress biomarker MDA and reduced the antioxidant level of reduced glutathione mostly in glyphosate-based herbicides intoxicated group due to exhaustion of GSH in a conjugation reaction or lowering through its biosynthesis pathway (Turkmen et al., 2019). Free radical scavengers with antioxidant activity in the cells act on ameliorating the damaging effects provoked by reactive free radicals. Apart from this oxidative stress indicator, hepatic, renal, and cardiac function are useful bioindicators of exposure to the pollutants as glyphosate-based insecticides in the eco-environment (Kalender et al., 2010). In comparison with the control catfish group in this study, serum AST and ALT levels significantly elevated in glyphosate intoxicated group due to hepatocyte damage resulted from liver injury (Jasper et al., 2012; Youness et al., 2016). Reducing albumin and total protein levels in serum in this study due to reducing the oxidative phosphorylation process, that can lead to reducing protein absorption and protein synthesis followed by enhancing the catabolic process (Ghanbari et al., 2016). Serum creatinine and urea are helpful biomarkers in assessment in vivo and in vitro renal functions studies which were elevated in the group intoxicated with glyphosate as recorded by Çavuşoğlu et al. (2011). This may be due to impairment in the renal tubular destruction and impaired glomerular filtration in catfish that exposed to glyphosate insecticides in water (Çavuşoğlu et al., 2011). The electrolytes concentration in fish is responsible for the osmoregulation process during the stress condition (Ogamba et al., 2011). So that, the electrolytes are essential for all types of tissue function, the presence of alkali metal ions as $\left(\mathrm{Na}^{+}, \mathrm{K}^{+}, \mathrm{Ca}^{2+}\right.$ are vitally important for the stimulation of the enzyme activity. On the other hand, the critical losses of body electrolyte may reduce the osmotic concentration and leads to circulatory failure. The lower concentration of $\mathrm{Na}^{+}$and $\mathrm{Ca}^{+}$in the glyphosate exposure group due to the proximal tubules damage resulted from renal toxicity. And also, the higher serum $(\mathrm{K}+)$ concentration in the glyphosate exposed group due to the induction of oxidative damage (Ambali et al., 2010).

Mulberry leaves have a long history of using in traditional medicine in different countries. A wide range of nutritive content like amino acids, minerals, fatty acids, vitamins as well as quercetin, anthocyanins, chlorogenic, polysaccharides acid, and rutin that have been detected in mulberry depending on the cultivars and maturity stages (Yuan and Zhao, 2017). Mulberry leaves act as beneficial sources for antioxidant molecules like phenols, terpenoids, flavonoids, and flavonols (Iqbal et al., 2012). Taking responsibility for a significant decrease in MDA level and the elevated GSH level in the treated groups with M.albus could be attributable to its antioxidant properties in lowering peroxidative activity in the cells. It also includes various polyhydroxy alkaloids such as stilbenoids which are supposed to act as resveratrol and oxyresveratrol, flavonoids going to act as quercetin and kaempferol, rutin, and medicinal imino-sugars (Song et al., 2009). The dietary adding $M$. albus has led to an improvement in GOT and GPT enzyme activities in hepatic tissue and reduced the oxidative destruction through reducing ROS generation and cellular oxidation component and increasing antioxidant molecules activity ( $\mathrm{Li}$ et al., 2020), and the hepatoprotective activity resulted from antioxidant activity in alkaloid as flavonoids anti-carcinogenic activities (Majinda et al., 2011). The improvement in the levels of $\mathrm{Ca}$ and $\mathrm{Na}$ in the Glyph/M. albus group may be due to the high nutritive value of the dried leaves of $M$. albus that are mainly contain fibers, protein, carbohydrates, ash and are rich in $\beta$-carotene, ascorbic acid, calcium, iron, sodium, zinc and vital polyunsaturated fatty acids linoleic acid and essential amino acids which were required for normal metabolism and growth (Sarkar et al., 2018).

Bioaccumulation of glyphosate in animal tissues is not expected to be high due to its high water solubility, accompanied by a very low log Pow (-3.2), and its ionic character (European Commission, 2002). However, the bioaccumulation study showed that glyphosate accumulated in catfish muscle in both groups (Glyphosate and Glyphosate+Mulberry groups). These results agree with Contardo-Jara et al. (2009). Mulberry extract not significantly decrease the concentration of glyphosate in fish muscle.

Glyphosate-based herbicide in this study has led to a serious histopathological lesion in the gills, brain, labyrinth organ, hepatic, renal, and spleen. Neuronal changes in the brain were reported that detect a degenerative focus in neuronal bodies in the telencephalon of fish and necrotic changes in an intoxicated group with glyphosate (Ramírez-Duarte et al., 2008). Additionally, it can disrupt the barrier function through inducing opening in the blood-brain barrier that lead to changes in glucose metabolism in neuronal cell and glucose up taken in microvascular endothelial of the brain (Martinez and Al-Ahmad, 2019). The thrombus formation in brain blood vessels and an elevation of the white blood cells and platelets were recorded due to oxidative stress damage in the current result and this supported by Naz et al. (2019). The neuro-protective effect of mulberry leaves on brain histopathological lesion in a treated group 
due to its increasing antioxidant activity which reduces ROS formation and improving the blood-brain barrier permeability, with elevation in neuron density in the subregion of the hippocampus and reverses action A $325-35-$ which induced neuronal injury and apoptosis inhibition through down regulation mRNA levels of an apoptotic protease-activating factor (Apaf1) (Rebai et al., 2017).

Gills inflammation, degeneration, and necrosis were detected in the group intoxicated with glyphosate (Ramírez-Duarte et al., 2008) which was improved after consuming the mulberry leaves which lead to improve the respiratory function in the brachia by elevating GOT activities and hemoglobin level in RBCs of crucian carp (Li et al., 2020). While the histopathological changes in the labyrinth elastic cartilage in glyphosate induced toxicity group which is converted to fibrocartilage due to a severe depletion of serum Mn. Chondroitin sulfate synthesis depends on Mn (manganese), and its deficiency leads to osteoporosis and osteomalacia (Samsel and Seneff, 2015). Glyphosate also induces stiffening in the cell membrane and the appearance of cytoskeleton structures at a subcellular level of the skin which improved due to antioxidant activity and manganese content of mulberry leaves (Heu et al., 2012).

The histopathological changes in kidney tissue as degeneration, necrosis and atrophy in the renal tubular epithelium and interstitial fibrosis kidneys, thrombosis in the lumen of renal blood induced by glyphosate as supported by Naz et al. (2019). The treated group with mulberry revealed high normal intact renal glomeruli, healthy tubular epithelium, and normal renal blood vessels due to the improving the renal damage which lowering $\mathrm{mALB} / \mathrm{Cre}$ (microalbumin/creatinine) ratio in urine and regenerate the tubular epithelial cells and the epithelial thickening of renal cystic that finding supported by Zhang et al. (2019). The liver of catfish which is intoxicated with glyphosate showed thickening of the portal vein and fibroblastic proliferation and hyalinization into the wall. The injury of both walls of the blood vessel and blood sinusoid due to glyphosate metabolites (aminom-ethyl phosphoric acid (AMPA)) and formaldehyde which are found in environments in soil and rivers which supported by Saleh et al. (2018). The mulberry extract helps to improve liver injury induced by alcohol through decreasing liver injury biomarkers levels (AST, ALT and ALP), triglyceride (TG), and cholesterol (TC). It also reduces lipid accumulation and lipogenesis, improves the transportation of fatty acid and oxidation process, decreased oxidative stress, and facilitated anti-inflammation as reported by Tang et al. (2013). The spleen in the intoxicated fish with glyphosate revealed depletion of lymphocytes in white pulp impacted with lymphocytes the protected group exhibited increased lymphocytes in white pulp the mulberry group showed an increased population of lymphocytes in white pulp and that in agreement with Zhao et al. (2020) who found thymus and spleen in mulberry treated groups were greater in comparison with control.

\section{CONCLUSION AND RECOMMENDATIONS}

The current modeling analysis derived from a research study on glyphosate-based herbicides induced toxicity in catfish via induction of ROS and the possible protective rules of $M$. albus leaves on glyphosate toxicity were discussed in this study. Hepato-nephron toxicity was induced by glyphosate is due to oxidative damage which is attributed to serum biochemical parameters and histopathological abnormalities and also, it was accumulated in the muscle tissue. The improvements in liver and kidney parameters of catfish may be due to mulberry leaves powder. It was concluded that the mulberry leaves herbal extract is being ecofriendly antioxidant compound with a highly natural protective effect against glyphosate induced toxicity. Finally, we recommended the following study to use different levels from M.albus leaves powder and increase the duration of study to be more than three months to record better result for using $M$. albus in different species.

\section{ACKNOWLEDGMENTS}

Many thanks for Professor Dr. Mahmoud Arafa (Arafa M.) Biochem. Department of Animal Health Research Institute in Dokki to assist in the preparation and estimation of blood biochemistry.

\section{NOVELTY STATEMENT}

The prolonged -relased of agriculture wastes has led to elevate the level of pesticides especially glyphosate which was reached to aquatic environment. research has been carried out on catfish to detect the toxic impacts of glyphosate and the protective effect of adding Mullberry leaves against glyphosate intoxication in cat fish.

\section{AUTHOR'S CONTRIBUTION}

El-Sheshtawy $\mathrm{Sm}$ and Samak $\mathrm{DH}$ Contributed experemiental desigh and biochemical analysis ,AbdElhafeez Ms determined glyphosate residue in catfish muscle by HPLC and statistical analysis of the method validation parameters and $\mathrm{Nada} \mathrm{MM}$ contributed histopathological Examination. All authors participated in writing the manuscript.

\section{AbBreviations}

Glyphosate (Glyph); Mulberry Albus leaves (M. albus); 
Malondialdehyde (MDA) reduced glutathione (GSH); Alanine amino transferase (ALT); aspartate amino transferase (AST).

\section{FUNDING}

The study has not taken any specific grant from funding agencies in the public, commercial, or not-for-profit sectors.

\section{CONFLICT OF INTEREST}

The authors have declared no conflict of interests.

\section{REFERENCES}

-Adedeji O, Okocha R (2012). Overview of pesticide toxicity in fish. Adv. Environ. Biol., pp. 2344-2352.

-AHB W (2006). Tietz clinical guide to laboratory tests. 4. St. Louis, Missouri. WB Saunders Company, Elsevier Press.

-Ambali SF, Onukak C, Idris SB, Yaqub LS, Shittu MU, Aliyu H, Kawu MU (2010). Vitamin C attenuates short-term hematological and biochemical alterations induced by acute chlorpyrifos exposure in Wistar rats. J. Med. Med. Sci., 1: 465-477.

-Annett R, Habibi HR, Hontela A (2014). Impact of glyphosate and glyphosate-based herbicides on the freshwater environment. J. Appl. Toxicol., 34: 458-479.

-AOAC (2000). Official method of analysis. $17^{\text {th }}$ ed. 2000, vol. 2. No. 990.33. Natural Toxins, Association of Official Analytical Chemist, Gaithersburg, MD, USA: 20-22.

-Ayanda OI, Oniye S, Auta J, Ajibola V (2015). Acute toxicity of glyphosate and paraquat to the African catfish (Clarias gariepinus, Teugels 1986) using some biochemical indicators. Trop. Zool., 28: 152-162.

- Bai SH, Ogbourne SM (2016). Glyphosate: Environmental contamination, toxicity and potential risks to human health via food contamination. Environ. Sci. Pollut. Res., 23: 18988-19001.

- Battaglin WA, Meyer M, Kuivila K, Dietze J (2014). Glyphosate and its degradation product AMPA occur frequently and widely in US soils, surface water, groundwater, and precipitation. J. Am. Water Resour. Assoc., 50: 275-290.

- Beutler E (1963). Improved method for the determination of blood glutathione. J. Lab. Clin. Med., 61: 882-888.

-Boligon AA, Piana M, Kubiça TF, Mario DN, Dalmolin TV, Bonez PC, Weiblen R, Lovato L, Alves SH, Campos MM (2015). HPLC analysis and antimicrobial, antimycobacterial and antiviral activities of Tabernaemontana catharinensis $\mathrm{A}$. DC. J. Appl. Biomed., 13: 7-18.

- Cao Y, Ma ZF, Zhang H, Jin Y, Zhang Y, Hayford F (2018). Phytochemical properties and nutrigenomic implications of yacon as a potential source of prebiotic: Current evidence and future directions. Foods, 7: 59.

- Çavuşoğlu K, Yapar K, Oruc E, Yalçın E (2011). Protective effect of Ginkgo biloba L. leaf extract against glyphosate toxicity in Swiss albino mice. J. Med. Food, 14: 1263-1272.

- Chan E, Lye PY, Wong SK (2016). Phytochemistry, pharmacology, and clinical trials of Morus alba. China J. Nat. Med., 14: 17-30.

- Chaufan G, Coalova I, Molina MDCRD (2014). Glyphosate commercial formulation causes cytotoxicity, oxidative effects, and apoptosis on human cells: differences with its

\section{active ingredient. Int. J. Toxicol., 33: 29-38.}

- Contardo-Jara V, Klingelmann E, Wiegand C (2009). Bioaccumulation of glyphosate and its formulation Roundup Ultra in Lumbriculus variegatus and its effects on biotransformation and antioxidant enzymes. Environ. Pollut., 157(1): 57-63.

-Doumas BT, Watson WA, Biggs HG (1997). Albumin standards and the measurement of serum albumin with bromcresol green. Clin. Chim. Acta, 258: 21-30.

-European Commission, Directorate E1-Plant Health (2002). Glyphosate, 6511/VI/99- Final, Review Report for the Active Substance Glyphosate.

- Gallegos CE, Bartos M, Bras C, Gumilar F, Antonelli MC, Minetti A (2016). Exposure to a glyphosate-based herbicide during pregnancy and lactation induces neurobehavioral alterations in rat offspring. NeuroToxicol., 53: 20-28.

- Ghanbari E, Nejati V, Khazaei M (2016). Improvement in serum biochemical alterations and oxidative stress of liver and pancreas following use of royal jelly in streptozotocininduced diabetic rats. Cell J. (Yakhteh), 18: 362.

-Glusczak L, Loro VL, Pretto A, Moraes BS, Raabe A, Duarte MF, Da Fonseca MB, De Menezes CC, De Sousa Valladã DM (2011). Acute exposure to glyphosate herbicide affects oxidative parameters in piava (Leporinus obtusidens). Arch. Environ. Contamin. Toxicol., 61: 624-630.

- Govind P (2011). A review of fish model in experimental pharmacology. Int. Res. J. Pharm., 2: 33-36.

-Henry R, Cannon DC, Winkelman JW (1974). Clinical Chemistry: Principles and Techniques, Herper and Roe, Maryland, USA. p. 543.

-Heu C, Berquand A, Elie-Caille C, Nicod L (2012). Glyphosateinduced stiffening of $\mathrm{HaCaT}$ keratinocytes, a peak force tapping study on living cells. J. Struct. Biol., 178: 1-7.

- Hou Q, Zhang J, Chen T, Zhao W, Li L (2020). Effects of dietary supplement of mulberry leaf (Morus alba) on growth and meat quality in rabbits. Indian J. Anim. Res., 54: 317321.

- Iqbal S, Younas U, Chan KW, Sarfraz RA, Uddin M (2012). Proximate composition and antioxidant potential of leaves from three varieties of Mulberry (Morus sp.): A comparative study. Int. J. Mol. Sci., 13: 6651- 6664.

-Jasper R, Locatelli GO, Pilati C, Locatelli C (2012). Evaluation of biochemical, hematological and oxidative parameters in mice exposed to the herbicide glyphosate-Roundup ${ }^{\circledR}$. Interdis. Toxicol., 5: 133-140.

-Ji HF, Li XJ, Zhang HY (2009). Natural products and drug discovery: can thousands of years of ancient medical knowledge lead us to new and powerful drug combinations in the fight against cancer and dementia? EMBO Rep., 10: 194-200.

- Kalender S, Uzun FG, Durak D, Demir F, Kalender Y (2010). Malathion-induced hepatotoxicity in rats: the effects of vitamins $\mathrm{C}$ and E. Food Chem. Toxicol., 48: 633-638.

- Katagi T (2010). Bioconcentration, bioaccumulation, and metabolism of pesticides in aquatic organisms. Rev. Environ. Contamin. Toxicol., Springer: 1-132.

- Li H, Lu L, Wu M, Xiong X, Luo L, Ma Y, Liu Y (2020). The effects of dietary extract of mulberry leaf on growth performance, hypoxia-reoxygenation stress and biochemical parameters in various organs of fish. Aquacult. Rep., 18: 100494.

- Martinez A, Al-Ahmad AJ (2019). Effects of glyphosate and aminomethylphosphonic acid on an isogeneic model of the 
human blood-brain barrier. Toxicol. Lett., 304: 39-49.

-Majinda R, Mazimba O, Motlhanka D (2011). Antioxidant and antibacterial constituents from Morus nigra. Afr. J. Pharm. Pharmacol. 5(6): 751-754.

-Naz S, Iqbal R, Ahmad A, Malik MF, Jabbar M, Yaqoob R, Saeed M, Hussain A, Aziz T, Haider SU (2019). 10. Effect of glyphosate on hematological and biochemical parameters of Rabbit (Oryctolagus cuniculus). Pure Appl. Biol., 8: 7892.

- Ogamba E, Inyang I, Azuma I (2011). Effect of paraquat dichloride on some metabolic and enzyme parameters of Clarias gariepinus. Curr. Res. J. Biol. Sci., 3: 186-190.

- Ohkawa H, Ohishi N, Yagi K (1979). Assay for lipid peroxides in animal tissues by thiobarbituric acid reaction. Analyt. Biochem. 95: 351-358.

-Perakis N, Wolff C (1984). Kinetic approach for the enzymic determination of creatinine. Clin. Chem., 30: 1792-1796.

-Ramírez-Duarte WF, Rondón-Barragán IS, Eslava-Mocha PR (2008). Acute toxicity and histopathological alterations of Roundup ${ }^{\circledR}$ herbicide on "cachama blanca" (Piaractus brachypomus). Pesquisa Vet. Brasil., 28: 547-554.

- Rebai O, Belkhir M, Fattouch S, Amri M (2017).Phytochemicals from mulberry extract (Morus sp.): Antioxidant and neuroprotective potentials. J. App. Pharma. Sci., 7: 217-222.

- Reitman S, Frankel S (1957). A colorimetric method for the determination of serum glutamic oxalacetic and glutamic pyruvic transaminases. Am. J. Clin. Pathol., 28: 56-63.

- Saleh SM, Elghareeb TA, Ahmed MA, Mohamed IA, El-Din HAE (2018). Hepato-morpholoy and biochemical studies on the liver of albino rats after exposure to glyphosateRoundup ${ }^{\circledast}$.J. Basic Appl. Zool., 79: 48.

-Samsel A, Seneff S (2015). Glyphosate, pathways to modern diseases III: Manganese, neurological diseases, and associated pathologies. Surgical neurology international 6.

-Sánchez JAA, Junior ASV, Corcini CD, Da Silva JC, Primel EG, Caldas S, Klein RD, Martins CDMG (2017). Effects of Roundup formulations on biochemical biomarkers and male sperm quality of the livebearing Jenynsia multidentata. Chemosphere, 177: 200-210.

-Sandrini JZ, Rola RC, Lopes FM, Buffon HF, Freitas MM, Martins CDMG, Da Rosa CE (2013). Effects of glyphosate on cholinesterase activity of the mussel Perna perna and the fish Danio rerio and Jenynsia multidentata: in vitro studies. Aquat. Toxicol., 130: 171-173.

-Sarkar T, Mogili T, Doss SG, Sivaprasad V (2018). Tissue culture in mulberry (Morus spp.) intending genetic improvement, micropropagation and secondary metabolite production: A review on current status and future prospects, biotechnological approaches for medicinal and aromatic plants. Springer: pp. 467-487.

- Sas I (2001). SAS/WATTM User's Guide. SAS Institute. Inc., Cary NC.

- Searcy R (1967). A new photometric method for serum urea nitrogen determination. Am. J. Med. Technol., 33: 15-20.

- Song W, Wang HJ, Bucheli P, Zhang PF, Wei DZ, Lu YH (2009). Phytochemical profiles of different mulberry (Morus sp.) species from China. J. Agric. Food Chem., 57: 91339140 .

- Sun L, Kong D, Gu W, Guo X, Tao W, Shan Z, Wang Y, Wang N (2017). Determination of glyphosate in soil/sludge by high performance liquid chromatography. J. Chromatogr., A 1502: 8-13.

- Suvarna SK, Layton C, Bancroft JD (2013). Bancroft's theory and practice of histological techniques. $7^{\text {th }}$ ed. Churchill Livingstone, Elsevier, England.

-Tang CC, Huang HP, Lee YJ, Tang YH, Wang CJ (2013). Hepatoprotective effect of mulberry water extracts on ethanol-induced liver injury via anti-inflammation and inhibition of lipogenesis in C57BL/6J mice. Food Chem. Toxicol., 62: 786-796.

-Thakur K, Zhang YY, Mocan A, Zhang F, Zhang JG, Wei ZJ (2019). 1-Deoxynojirimycin, its potential for management of non-communicable metabolic diseases. Trends Food Sci. Technol., 89: 88-99.

-Thomas L (1998). Clinical laboratory diagnostics: Use and assessment of clinical laboratory results. TH-books Verlagsgesellschaft.

- Trinder P (1969). Determination of blood glucose using 4-amino phenazone as oxygen acceptor. J. Clin. Pathol., 22: 246.

-Turkmen R, Birdane YO, Demirel HH, Kabu M, Incea S (2019). Protective effects of resveratrol on biomarkers of oxidative stress, biochemical and histopathological changes induced by sub-chronic oral glyphosatebased herbicide in rats. Toxicol. Res., 9: 238.

-USP (2019). <1225> Validation of compendial procedures and $<621>$ Chromatography. Rockville, Rockville, MD: United States Pharmacopeia.

-WHO (2001). World Health Organization.Water Analysis Methods, New York, pp. 44-87.

-Youness ER, Agha FE, El-Toukhy SE, El-Naggar SM, Selim AA, Ibrahim AM (2016). The protective effect of orange juice on glyphosate toxicity in adult male mice. J. Chem. Pharm. Res. 8: 13-28.

-Yuan Q, Zhao L (2017). The Mulberry (Morus alba L.) Fruit- A Review of Characteristic Components and Health Benefits. J. Agric. Food Chem., 65: 10383-10394.

-Zhang L, Su S, Zhu Y, Guo J, Guo S, Qian D, Ouyang Z, Duan JA (2019). Mulberry leaf active components alleviate type 2 diabetes and its liver and kidney injury in $\mathrm{db} / \mathrm{db}$ mice through insulin receptor and TGF- $\beta /$ Smads signaling pathway. Biomed. Pharmacother., 112: 108675.

-Zhao X, Yang R, Bi Y, Bilal M, Kuang Z, Iqbal H, Luo Q (2020). Effects of dietary supplementation with mulberry (Morus alba L.) leaf polysaccharides on immune parameters of weanling pigs. Animals, 10: 35.

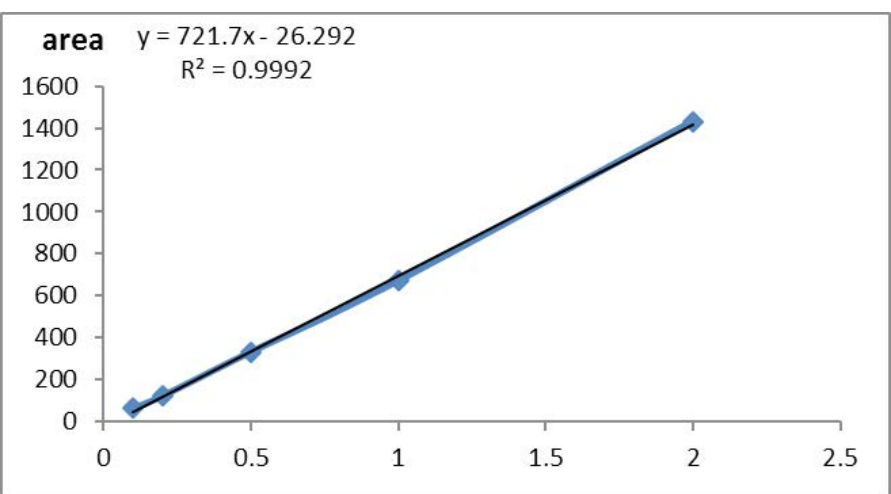

Supplementary Figure S1: Standard curve of glyphosate conc. versus peak area. 


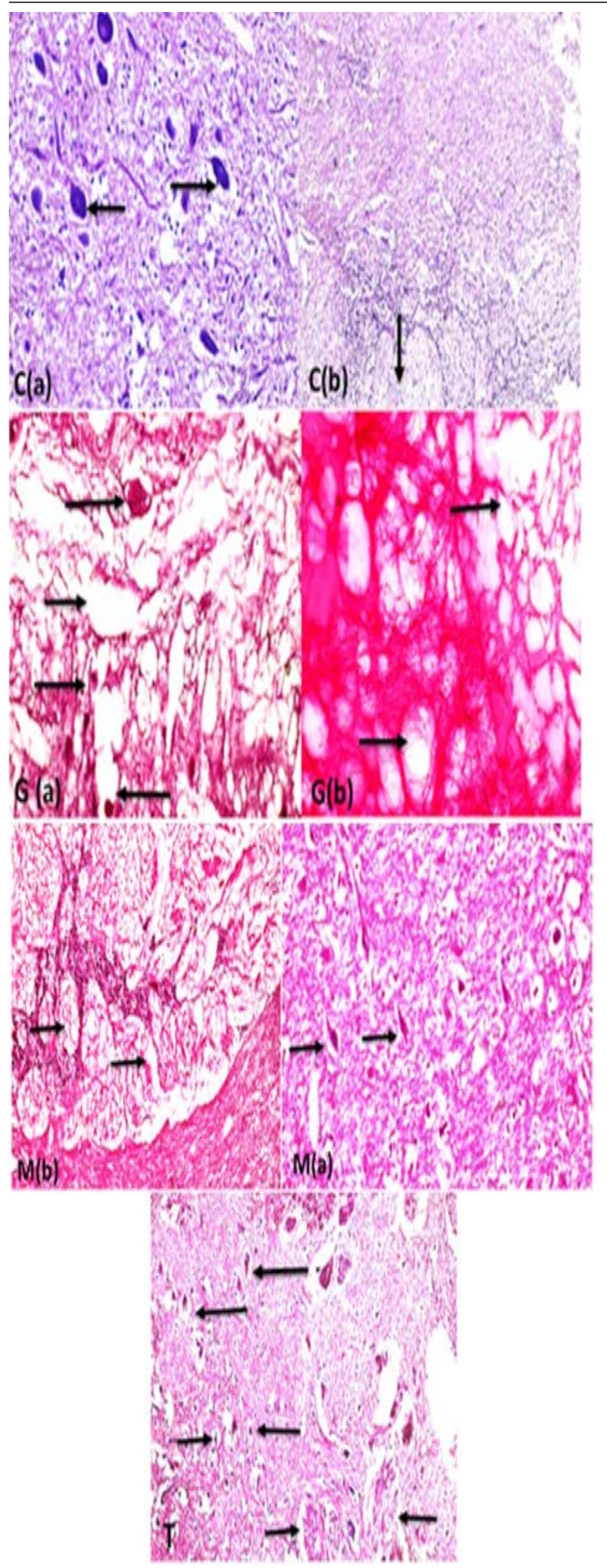

Supplementary Figure S2: C (a):Brain fish (gray matter) control showing normal neurons with basophilic cytoplasm and central nuclei (arrows) with intact brain parenchyma
( $\mathrm{H}$ and $\mathrm{EX} 400)$ and $\mathrm{C}(\mathrm{b})$ : the white matter nerve fibers showing intact nerve fibers in brain medulla (arrow) $(\mathrm{H}$ and EX200.G (a): brain (gray matter fish intoxicated with glyphosate) showing severe acidophilic necrosis of neurons retracted shrinkage of the nuclei and cells (long arrows) with cavitations of brain moth eaten appearance (short thin arrow) and thrombosis of blood capillary (short thick arrow) (StainH and EX400) G(b): white matter of brain fish showing severe degeneration of white matter nerve fibers (spongiosis) (long arrows) (Stain $\mathrm{H}$ and EX200). M (a) brain showing highly intact healthy brain gray matter parenchyma and healthy basophilic neurons (arrows) $(\mathrm{H}$ and EX400) $\mathrm{M}(\mathrm{b})$ showing marked healthy nerve fibers neurons in white matter (arrows) $\mathrm{H}$ and EX200).T: Brain gray and white matter in protected group showing neurons retain to normal structure (long arrows) in compare with glyphosate group neurons, but still some neurons suffering from necrosis (small retracted pyknotic nuclei)(short thin arrows), marked improvement of brain parenchma with no spongiosis, with marked regeneration of nerve fibers neurons (short thick arrows) (H and EX200).

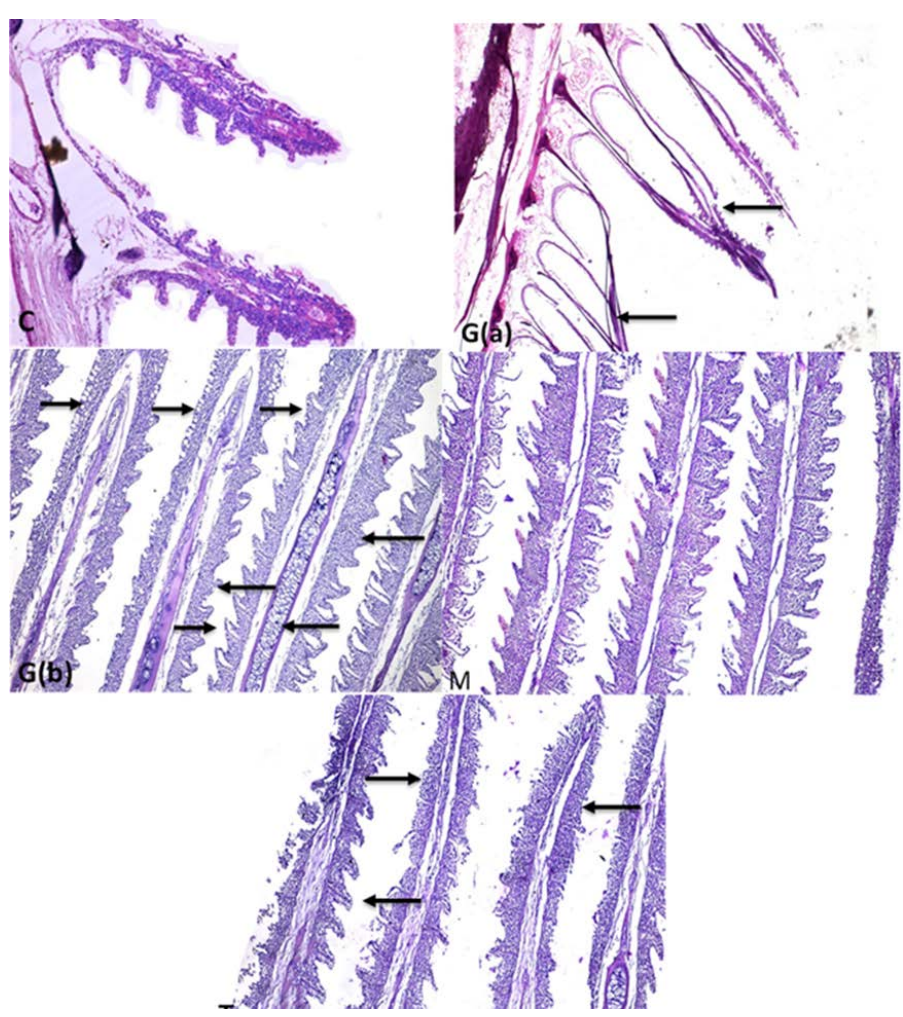

Supplementary Figure S3: C: Fish gills showing gills with normal primary and secondary gill filament with normal cellular structure and central blood supply of gill filaments (H and EX100) G (a):Gills fish showing necrosis and degeneration of all epithelial cells covering gill filaments (gill filaments appeared bar from all cells) (arrows)( $\mathrm{H}$ and EX4) $G(b)$ : some parts of gills showing inter lamellar hyperplasia, inflammatory infiltration of mononuclear cells ( long thick arrows) in gill filaments with mucus cells proliferation (long thin arrows) and chondrocytes proliferation in the center of gill filaments (short thin 
arrow) with lamellar fusion of gill secondary filaments in the upper part (thick short arrow) (StainH and EX100) M gills: showing highly intact healthy gill filaments with normal secondary non fused gill filament with central blood supply (H and EX100) T: gills showing improved gill filaments structure (long arrow) with still presence of gill necrosis (short arrows) (H and EX100).
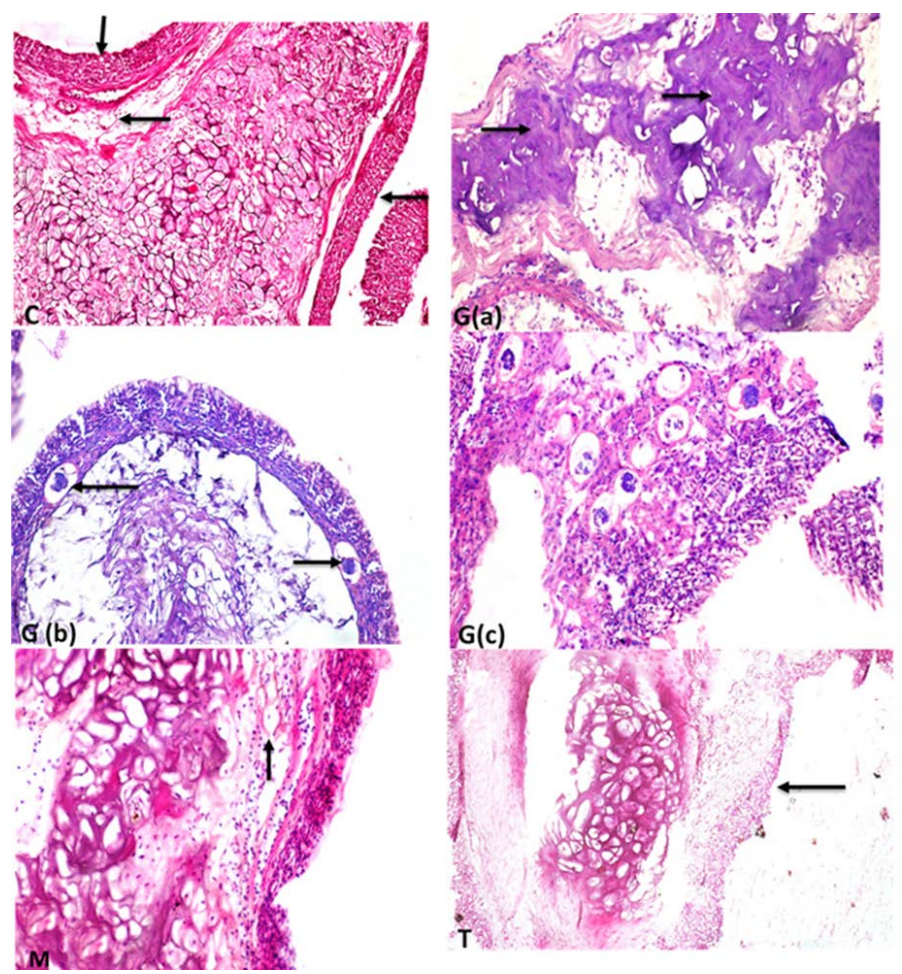

Supplementary Figure S4: C: labyrinth organ showing central elastic cartilage in the center with normal maize like structure epithelium tissues in the periphery (short arrow) and normal blood capillaries (long arrow) (StainH and EX200). G(a) labyrinth organ of fish showing conversion of elastic cartilage into fibrocartilage (arrows) (H and EX400). G(b) labyrinth organ with thrombosis (arrows) of blood capillaries (H and EX200) (StainH and EX100 ). G(c) high power of previous picture showing thrombosis of blood capillaries ( $\mathrm{H}$ and Ex400). $\mathrm{M}$ :elastic cartilage normal with maize like epithelium structure in the periphery and healthy blood supply (arrow)(H and EX400)T: showing intact elastic cartilage with few some degenerative changes and degeneration of epithelial cell in maize like structure in the periphery(long arrow) $(\mathrm{H}$ and EX200).

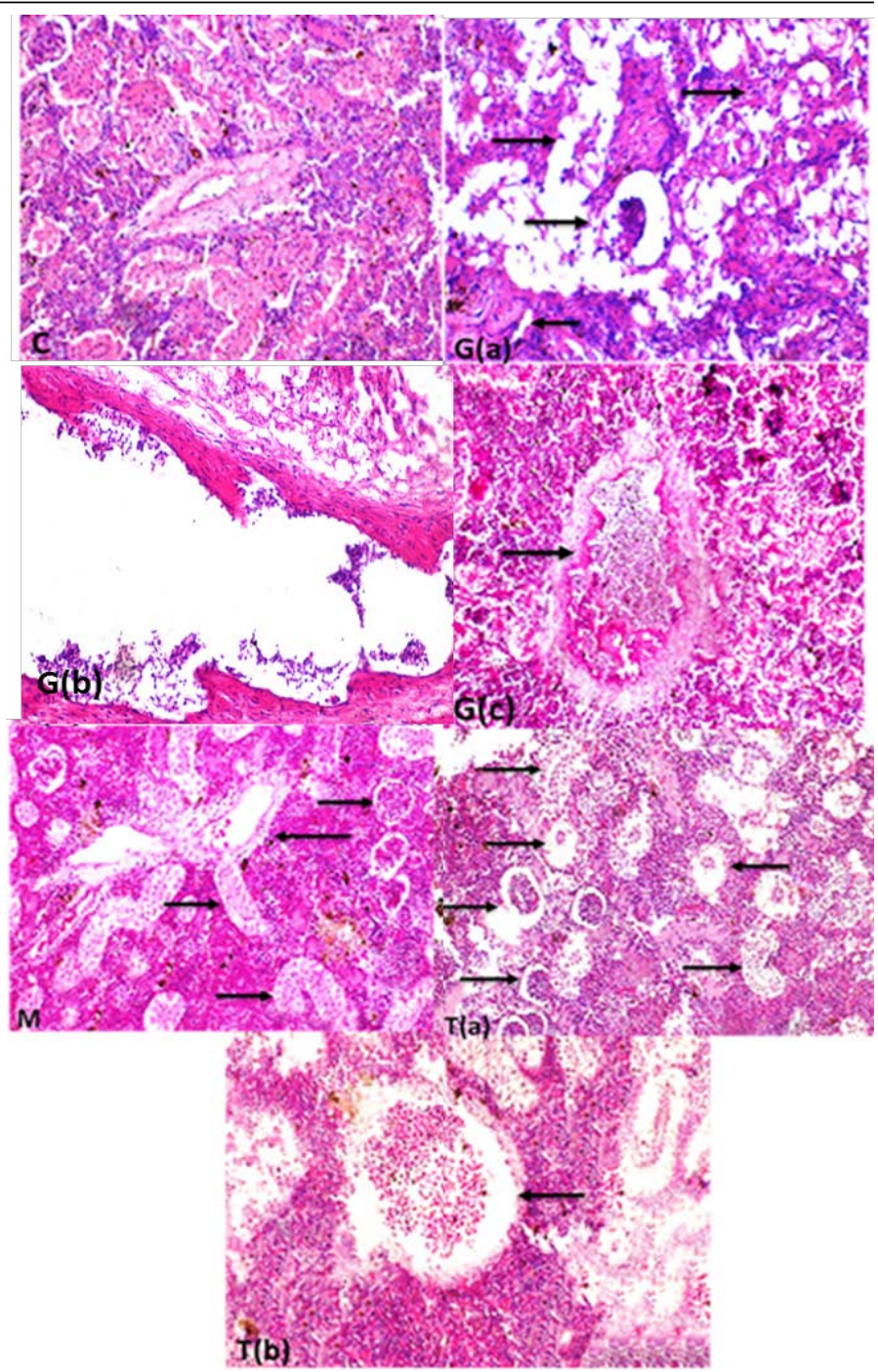

Supplementary Figure S5: (c) kidney showing glomeruli with normal kidney tubular epithelium and normal circumscribed wall thickness of blood vessel( $\mathrm{H}$ and EX400).G (a): Kidney fish intoxicated with glyphosate showing atrophied renal glomeruli (long thin arrow) degeneration and necrosis of renal tubular epithelium (short arrows) and interstitial fibrosis (thick long arrow), $(\mathrm{H}$ and EX400) G(b) blood vessels in kidneys showing folding of all wall tunics into the lumen with severe thickening in the wall of blood vessels folding into lumen ( $\mathrm{H}$ and EX400) ,G(c) kidneys showing thrombosis in the lumen of renal blood vessel attached to the wall with accumulated RBCs and leukocytes ( $\mathrm{H}$ and EX400) M: Kidney fish showing healthy glomeruli (long thick arrow), and highly improved renal tubular epithelium (long thin arrows) with normal blood vessels wall (short thick arrow) (H and EX200) $\mathrm{T}(\mathrm{a})$ :kidneys fish showing high intact renal glomeruli (long thick arrow), and normal renal tubular epithelium of renal tubuli (long thin arrow) but still present of degree of degenerative changes of some renal tubules (short thick arrow)(H and Ex200) T(b): renal blood vessels with normal circumscribed vessels wall with normal thickness and normal blood content (arrow)(H and EX400) $\mathrm{H}$ and $\mathrm{E}$ semi quantitative scoring of hepatic lesions. 


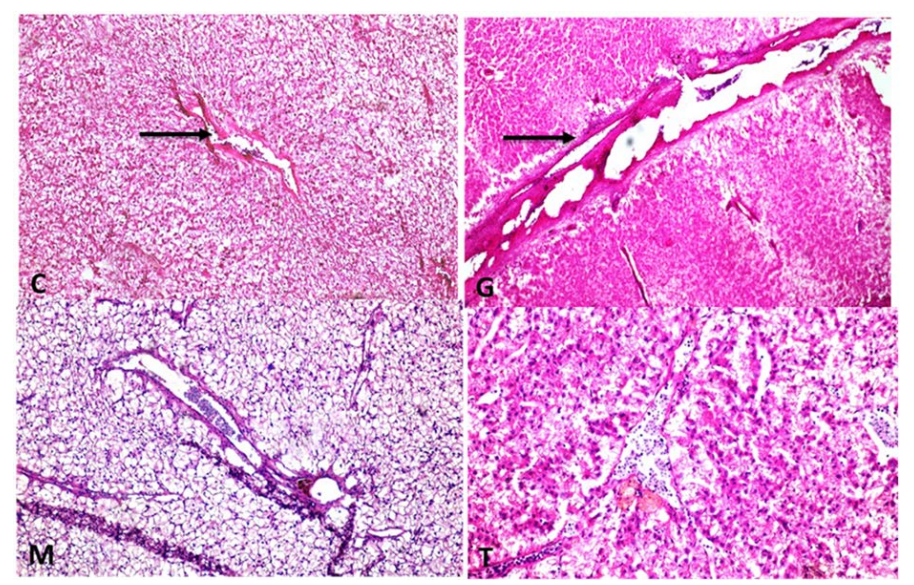

Supplementary Figure S6: C: Liver showing normal thickeness portal vein wall (H and EX100)G: liver showing portal vein wall thickening, hyalinization with folding into lumen ( $\mathrm{H}$ and EX100) M: liver with normal thickness portal vein wall ( $\mathrm{H}$ and EX200) T: Liver with normal thin thickness portal vein wall (H and EX200).

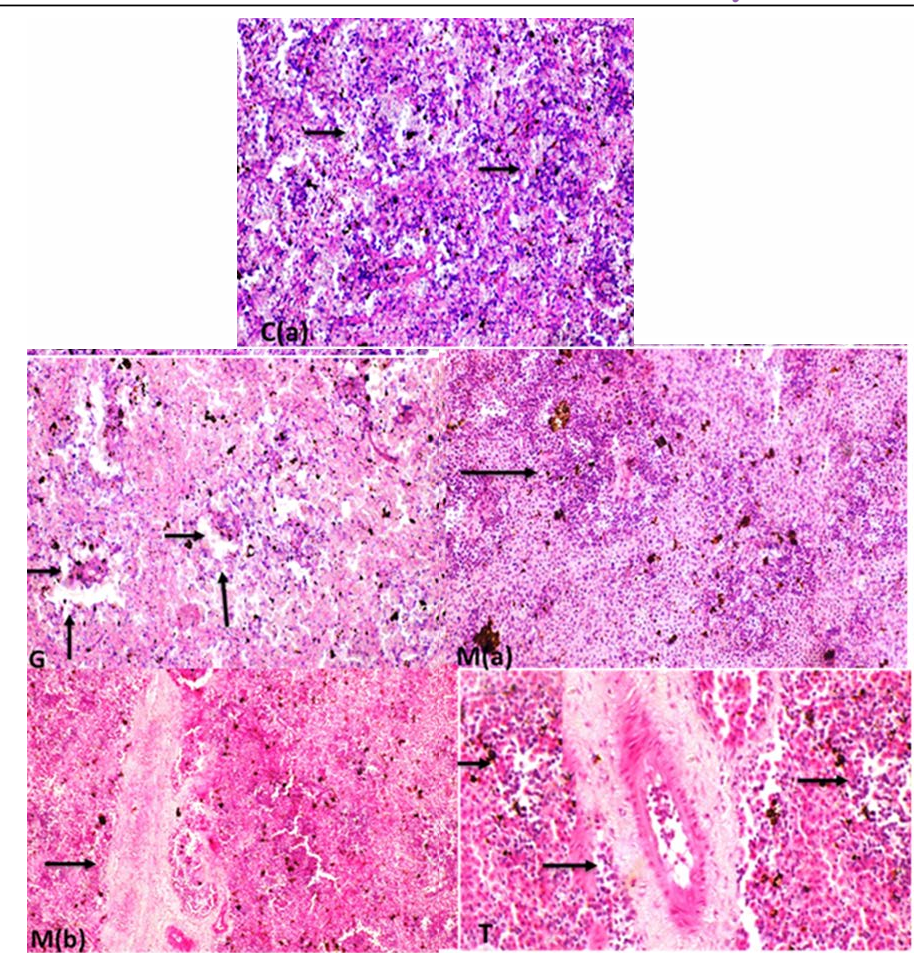

Supplementary Figure S7: C(a): spleen white pulp impacted with lymphocytes (arrows)(H and EX200). $\mathrm{C}(\mathrm{b})$ : Spleen fish showing normal diameter central arteriole (H and EX400) G: spleen fish revealing depletion of lymphocytes in white pulp ( long arrows) with normal diameter central arteriole (short arrows) (H and EX200) $\mathrm{M}(\mathrm{a})$ : increase lymphocytes in white pulp (arrow) $(\mathrm{H}$ and EX400) $M(b)$ :high increase in periarterial lymphatic sheath (arrow) (H and Ex200). T: increase lymphocytes in white pulp with dilated blood vessels and increase periarterial lymphatic sheath. 